\title{
Titrating lovaza from 4 to 8 to 12 grams/day in patients with primary hypertriglyceridemia who had triglyceride levels $>500 \mathrm{mg} / \mathrm{dl}$ despite conventional triglyceride lowering therapy
}

\author{
Charles J Glueck*, Naseer Khan, Muhammad Riaz, Jagjit Padda, Zia Khan and Ping Wang
}

\begin{abstract}
Background: Omega-3 fatty acids are important in treatment of severe primary hypertriglyceridemia (HTG). In 15 patients with severe primary HTG (TG >500 mg/dl despite conventional TG lowering therapy), we assessed efficacy-safety of sequential monthly treatment with Lovaza, 4 to 8 to $12 \mathrm{~g} /$ day.

Methods: With TG $>500 \mathrm{mg} / \mathrm{dl}$ despite Type $V$ diet, hyperinsulinemia and diabetes control, and fibric acids, Lovaza $(4 \mathrm{~g} / \mathrm{d})$ was added for 1 month, and if TG remained $>500 \mathrm{mg} / \mathrm{dl}$, increased to $8 \mathrm{~g} / \mathrm{d}$ for 1 month, and then to $12 \mathrm{~g} /$ $\mathrm{d}$ for 1 month, and subsequently reduced to $4 \mathrm{~g} /$ day for 4 months.

Results: Primary HTG, median TG 884 mg/dl, 14 men, 1 woman, all white, age $50 \pm 7$ years, 12 non-diabetic, 3 with stable diabetes control. Weight and diet held stable throughout. In 5 patients, after 1, 2, and 3 months on $4 \mathrm{~g} /$ day, TG fell <500, mean 1390 to $234(-83 \%, p<.0001)$, to $135(-90 \%, p<.0001)$, and $158 \mathrm{mg} / \mathrm{dl}(-89 \%, \mathrm{p}<.0001)$, with a negative TG slope, $p=.0013$. Non-HDLC fell from 320 to $177(-45 \%, p=.001)$, to $152(-53 \%, p=.0002)$, and to 163 $(-49 \%, p=.0004)$, with a negative slope, $p=.01$. In 10 patients, with Lovaza increased from 4 to 8 to $12 \mathrm{~g}, 3$ failed to respond. In 7 of these 10 patients, TG fell 37\% from 1075 to 672 on $4 \mathrm{~g}(p=.006)$, to 577 on $8 \mathrm{~g}(-46 \%, p=.0009)$, and to $428 \mathrm{mg} / \mathrm{dl}(-60 \%, \mathrm{p}<.0001)$ on $12 \mathrm{~g} /$ day, with a negative TG slope, $\mathrm{p}=.0018$. TG on $12 \mathrm{~g} /$ day was lower than on $8 \mathrm{~g} /$ day, $\mathrm{p}=.03$. Non-HDLC fell from 245 to $217 \mathrm{mg} / \mathrm{dl}(-11 \%)$ on $4 \mathrm{~g} /$ day, to 203 (-17\%, $\mathrm{p}=.01)$ on $8 \mathrm{~g} /$ day, and to $192(-22 \%, p=.003)$ on $12 \mathrm{~g} /$ day, with a negative slope, $p=.016$. Compared to pre-Lovaza baseline, no abnormal measures developed in safety tests. The 4, 8, and $12 \mathrm{~g} / \mathrm{d}$ Lovaza doses were well tolerated.
\end{abstract}

Conclusion: Titration of Lovaza from 4 to 8 to $12 \mathrm{~g} / \mathrm{d}$ safely offers an effective way to lower TG beyond conventional $4 \mathrm{~g}$ therapy.

Keywords: Triglyceride, Lovaza, Triglyceride-lowering therapy, Severe primary hypertriglyceridemia

\section{Introduction}

Omega-3 fatty acids of marine origin are safe, effective triglyceride (TG)-lowering agents [1-4], and are therapeutic in combined hyperlipidemia when added to statins [5]. Although the usual dose of the omega-3 marine long chain polyunsaturated fatty acid preparation (Lovaza) is $4 \mathrm{~g} /$ day, our previous studies [6-8] have shown that in patients receiving conventional triglyceride lowering regimens plus $4 \mathrm{~g}$ per day of Lovaza, further elevation of Lovaza to $8 \mathrm{~g}$,

\footnotetext{
* Correspondence: cjglueck@health-partners.org

Cholesterol Center, Jewish Hospital of Cincinnati, UC Health Building, 3200 Burnet Avenue, Cincinnati, $\mathrm{OH}$ 45229, USA
}

and if necessary, to $12 \mathrm{~g}$ safely further lowers TG. Overall, there appears to be a generally linear decrease in TG with increasing dose of Lovaza [7]. In other studies of hypertriglyceridemic patients, intake of 4.5, 7.5, and $12 \mathrm{~g}$ omega-3 fatty acids have been used effectively over short treatment durations [9-12].

There are many patients with primary and familial hypertrigyceridemia (HTG) where conventional treatment with diet, avoidance of alcohol, fibric acids, diabetes control, metformin (for hyperinsulinemia) [13], and $4 \mathrm{~g}$ /day Lovaza fails to lower TG below $500 \mathrm{mg} / \mathrm{dl}$, with TG levels remaining well above the therapeutic 
target [14] of $200 \mathrm{mg} / \mathrm{dl}$ [7]. In the Adult Treatment Panel-III guidelines, TG >500 was identified as severe, and a target for intervention, while an optimal TG level was $<150 \mathrm{mg} / \mathrm{dl}$ [14]. To the best of our knowledge there is no published data which indicates that systematic stepwise increments of Lovaza to 8 or $12 \mathrm{~g}$ per day would have therapeutic effectiveness in further normalizing TG in subjects on conventional TG lowering regimens which include Lovaza $4 \mathrm{~g} /$ day. We hypothesized, based on our clinical experience [6-8], that increasing Lovaza to 8 and then (if necessary) to $12 \mathrm{~g} /$ day would safely further lower TG in subjects with severe primary HTG who failed to lower TG below $500 \mathrm{mg} / \mathrm{dl}$ on conventional therapy including Lovaza $4 \mathrm{~g} /$ day.

Our specific aim in the current study was to assess effectiveness and safety of Lovaza 4, 8, and $12 \mathrm{~g}$ /day in 15 patients who were referred to us with primary HTG (TG>1000 mg/dl) and failed to lower TG below $500 \mathrm{mg} / \mathrm{dl}$ despite treatment with diet, avoidance of alcohol, fibric acids, treatment of type 2 diabetes mellitus, and, in the presence of hyperinsulinemia, metformin [13].

\section{Results}

There were 14 men, 1 woman, all white, mean age 50 , baseline mean \pm SD TG $1251 \pm 671 \mathrm{mg} / \mathrm{dl}$, with $25^{\text {th }}$, $50^{\text {th }}$ and $75^{\text {th }}$ percentile TG of 791,884 , and $1640 \mathrm{mg} / \mathrm{dl}$, Table 1. Baseline mean \pm SD HDL cholesterol was $29 \pm$ $9 \mathrm{mg} / \mathrm{dl}$ and non-HDLC was $274 \pm 104 \mathrm{mg} / \mathrm{dl}$, Table 1 .

Of the 3 subjects with type 2 diabetes, hemoglobin A1C (HbA1C) was held stable below 7.2\% throughout the study period in 2 , while in the third subject, mean HbA1C was $8.2 \%$, but stable throughout the study. All patients with type 2 diabetes were treated with metfor$\min 2.5 \mathrm{~g} /$ day. Of the 12 non-diabetic patients, $5 \mathrm{had}$ impaired fasting glucose $(\geq 100 \mathrm{mg} / \mathrm{dl}, 3$ of these 5 had hyperinsulinemia), and another 5 patients had hyperinsulinemia $(>24.9 \mathrm{uU} / \mathrm{ml})$. All of these 10 patients were treated with branded Metformin $2.5 \mathrm{~g} /$ day.
Two subjects had ApoE 2-3 heterozygosity, 1 ApoE 2-4, 6 were homozygous for the wild-type normal genotype (ApoE 3-3), and 6 were ApoE 3-4 heterozygotes, Table 1. ApoE 3-4 was more common in nonresponders (TG $>500 \mathrm{mg} / \mathrm{dl}$ despite $12 \mathrm{~g}$ Lovaza), Fisher's $\mathrm{p}=.04$, Table 1 . All 3 patients who failed to have sustained consistent reductions in TG below $500 \mathrm{mg} / \mathrm{dl}$ as Lovaza was increased from 4 to 8 to $12 \mathrm{~g} /$ day (nonresponders) had the ApoE 3-4 genotype, Table 1.

After 1 month on $4 \mathrm{~g}$ /day Lovaza, in 5 patients, TG fell well below $500 \mathrm{mg} / \mathrm{dl}$, from a baseline mean of $1390 \mathrm{mg} / \mathrm{dl}$ on conventional TG-lowering therapy to $234 \mathrm{mg} / \mathrm{dl}$ (mean reduced 83\%, p<.0001), Figure 1, Table 2. Mean TG fell $90 \%$ to $135 \mathrm{mg} / \mathrm{dl}$ and to $158 \mathrm{mg} / \mathrm{dl}$ $(-89 \%)$ after 2 and then 3 months on Lovaza 4 g/day $(\mathrm{p}<.0001$ for both), with a negative slope as TG fell, $\mathrm{p}=.0013$, Table 2 . In this group of 5 patients, mean TG $<200 \mathrm{mg} / \mathrm{dl}$ was maintained over 6 months treatment with $4 \mathrm{~g}$ /day Lovaza, Figure 1, Table 2. Mean non-HDL cholesterol fell from 320 to $177 \mathrm{mg} / \mathrm{dl}$ (decreasing 45\%, $\mathrm{p}=.001$ ) to $152(-53 \%, \mathrm{p}=.0002)$ to $163 \mathrm{mg} / \mathrm{dl}(-49 \%, \mathrm{p}=.0004)$, Table 2. In these 5 patients, on $4 \mathrm{~g}$ /day Lovaza compared to baseline, there were no changes in body weight ( $p>05)$, a single month period with lower systolic blood pressure $(\mathrm{p}=.04)$, and lower diastolic blood pressure $(\mathrm{p}=.05)$ in 2 of the 7 months on Lovaza, Table 3. In these 5 patients, there was no significant correlation between reduction in body weight (median 216 falling to 214) and reduction in TG (median $1170 \mathrm{mg} / \mathrm{dl}$ falling to $227 \mathrm{mg} / \mathrm{dl}$ ) from visit 0 to visit 1 , Spearman correlation $r=-.22, p>0.5$.

Of the 10 patients (baseline mean TG $1163 \mathrm{mg} / \mathrm{dl}$ on conventional TG-lowering therapy), as Lovaza was increased from 4 to 8 to $12 \mathrm{~g} /$ day, 3 failed to consistently respond, with mean TG at baseline $1369 \mathrm{mg} / \mathrm{dl}$, and after 3 months $1260 \mathrm{mg} / \mathrm{dl}$ while on Lovaza $12 \mathrm{~g} /$ day, Figure 2, Table 4. One of these three non-responders was the subject with type 2 diabetes whose mean HbA1C was stable at $8.2 \%$ throughout the study. In this subject,

Table 1 Baseline Lipids, lipoproteins, and APO E genotype in 15 patients with triglyceride $>500 \mathrm{mg} / \mathrm{dl}$

\begin{tabular}{|c|c|c|c|c|}
\hline & \multirow[t]{2}{*}{ Mean \pm SD } & \multicolumn{3}{|c|}{ Percentile } \\
\hline & & $25^{\text {th }}$ & Median & $75^{\text {th }}$ \\
\hline Age (years) & $50 \pm 7$ & 44 & 50 & 54 \\
\hline $\mathrm{TG}(\mathrm{mg} / \mathrm{dl})$ & $1251 \pm 671$ & 791 & 884 & 1640 \\
\hline Total cholesterol (mg/dl) & $303 \pm 107$ & 231 & 253 & 373 \\
\hline $\mathrm{HDLC}(\mathrm{mg} / \mathrm{dl})$ & $29 \pm 9$ & 24 & 27 & 36 \\
\hline Non-HDLC (mg/dl) & $274 \pm 104$ & 200 & 228 & 347 \\
\hline APOE genotype & $2-3$ & $2-4$ & $3-3$ & $3-4$ \\
\hline Responders $n=12$ & $2(17 \%)$ & $1(8 \%)$ & $6(50 \%)$ & $3(25 \%)$ \\
\hline Non-responders $n=3$ & 0 & 0 & 0 & $3(100 \%)$ \\
\hline Total $n=15$ & $2 / 15(13 \%)$ & $1 / 15(7 \%)$ & $6 / 15(40 \%)$ & $6 / 15(40 \%$ \\
\hline
\end{tabular}

APOE 3-4 was more common in non-responders, Fisher's $p=.04$. 


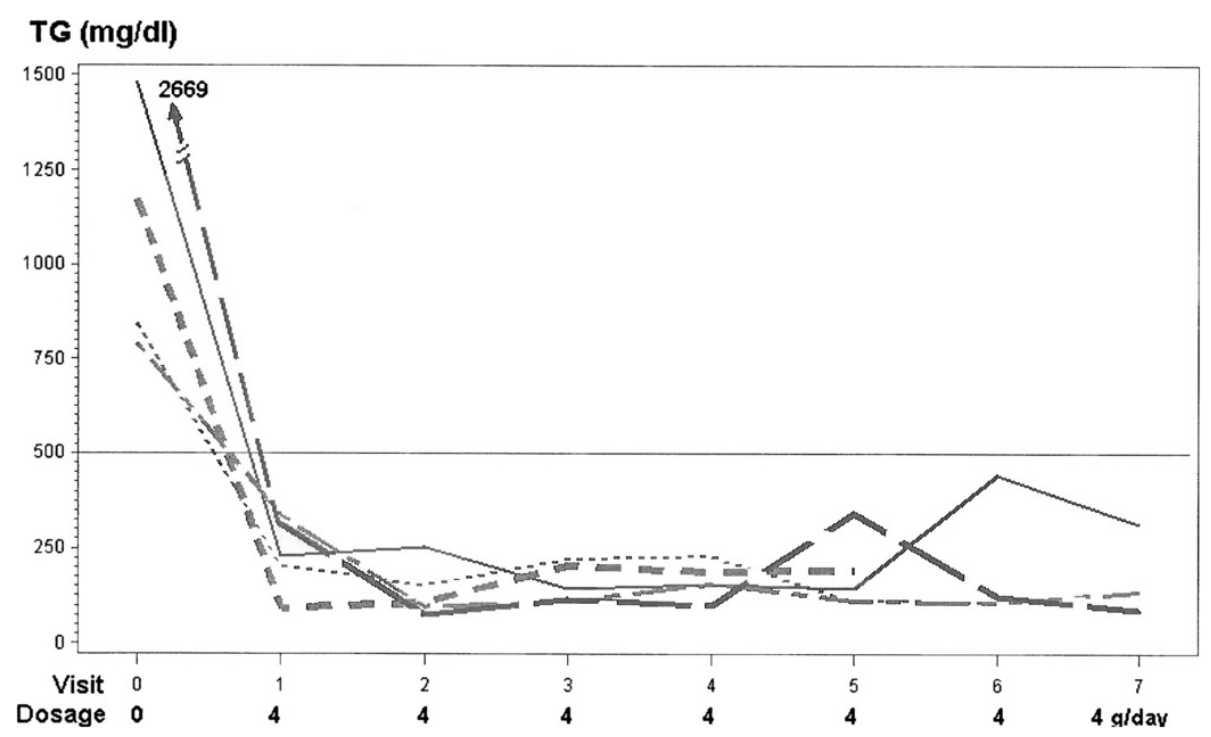

Figure 1 Five subjects whose triglyceride levels fell below $500 \mathrm{mg} / \mathrm{dl}$ on 4 grams of Lovaza/day.

TG fell from $859 \mathrm{mg} / \mathrm{dl}$ at baseline to $631 \mathrm{mg} / \mathrm{dl}$ on $4 \mathrm{~g} /$ day, rose to 697 on $8 \mathrm{~g} /$ day, and rose further to $1141 \mathrm{mg} /$ dl on $12 \mathrm{~g} /$ day, Figure 2. Then, when Lovaza was reduced to $4 \mathrm{~g} /$ day, TG rose to $2530 \mathrm{mg} / \mathrm{dl}$, Figure 2 . In this group of 3 patients, body weight was lower $(p=.02)$ at one of the 7 visits on Lovaza, without significant changes in systolic or diastolic blood pressure, Table 3.

In 7 patients who responded with TG lowering as Lovaza was increased to $12 \mathrm{~g}$ /day, Figure 3, Table 5, TG fell from a baseline mean on conventional TG lowering therapy of 1075 to $672 \mathrm{mg} / \mathrm{dl}$ on Lovaza $4 \mathrm{~g} /$ day (decreasing $37 \%, \mathrm{p}=.006)$, to 577 on $8 \mathrm{~g} /$ day $(46 \%, \mathrm{p}=.0009)$, and to $428 \mathrm{mg} / \mathrm{dl}$ on $12 \mathrm{~g} /$ day $(60 \%, \mathrm{p}<.0001)$, Table 5 , with a negative TG slope, $\mathrm{p}=.0018$, Table 5 . At the same time, mean non-HDLC fell $11 \%$ from 245 to $217 \mathrm{mg} / \mathrm{dl}$, fell $17 \%$ to $203 \mathrm{mg} / \mathrm{dl}$ ( $\mathrm{p}=.01$ ), and fell $22 \%$ to $192 \mathrm{mg} / \mathrm{dl}$ $(\mathrm{p}=.003)$, Table 5 . In this group of 7 patients, body weight was lower $(p=.002)$ at the last of 7 visits on Lovaza, systolic blood pressure was lower in one visit $(\mathrm{p}=.05)$, and diastolic blood pressure lower at 2 visits $(\mathrm{p}=.05, \mathrm{p}=.02)$, Table 3 . In 3 of these 7 patients after 1 month on $8 \mathrm{~g} /$ day Lovaza, TG levels had fallen to $<500 \mathrm{mg} / \mathrm{dl}$ (to 440,422 , and $371 \mathrm{mg} / \mathrm{dl}$ ), but their Lovaza was increased to $12 \mathrm{~g} /$ day, rather than being retained for 1 month at $8 \mathrm{~g} /$ day.

Of the 12 subjects without type 2 diabetes, 5 of whom had impaired fasting glucose (3 of these 5 had hyperinsulinemia), and 5 had hyperinsulinemia without IFG. All 10 patients were treated with metformin $2.5 \mathrm{~g} /$ day. Changes in weight, insulin and glucose were not significant (all $\mathrm{p}>0.6$ ) from visit 0 to visit 1 , and there was no

Table 2 TG and Non-HDLC at each visit during treatment in 5 subjects, where the Lovaza sequence was 4,4,4,4,4,4,4 g/day

\begin{tabular}{|c|c|c|c|c|c|c|c|c|c|}
\hline \multirow[t]{2}{*}{ Visit } & \multirow{2}{*}{$\begin{array}{l}\text { Dosage } \\
\text { (g/day) }\end{array}$} & \multicolumn{4}{|l|}{ TG (mg/dl) } & \multicolumn{4}{|c|}{ Non-HDLC (mg/dl) } \\
\hline & & Mean \pm SD & median & $\%$ change from Visit 0 & p (vs Visit 0) & Mean \pm SD & median & $\%$ change from Visit 0 & $p$ (vs Visit 0 ) \\
\hline 0 & 0 & $1390 \pm 766$ & 1170 & & & $320 \pm 134$ & 253 & & \\
\hline 1 & 4 & $234 \pm 97$ & 227 & $-83 \%$ & $<.0001$ & $177 \pm 65$ & 201 & $-45 \%$ & .001 \\
\hline 2 & 4 & $135 \pm 71$ & 107 & $-90 \%$ & $<.0001$ & $152 \pm 10$ & 147 & $-53 \%$ & .0002 \\
\hline 3 & 4 & $158 \pm 51$ & 142 & $-89 \%$ & $<.0001$ & $163 \pm 19$ & 171 & $-49 \%$ & .0004 \\
\hline 4 & 4 & $164 \pm 48$ & 155 & & $<.0001$ & $162 \pm 34$ & 169 & & .0004 \\
\hline 5 & 4 & $180 \pm 96$ & 144 & & $<.0001$ & $170 \pm 44$ & 151 & & .0007 \\
\hline 6 & 4 & $194 \pm 166$ & 114 & & $<.0001$ & $156 \pm 36$ & 159 & & .0005 \\
\hline \multirow[t]{2}{*}{7} & 4 & $179 \pm 120$ & 136 & & $<.0001$ & $139 \pm 30$ & 148 & & .0004 \\
\hline & & \multicolumn{4}{|c|}{$\begin{array}{l}\text { TG decreasing slope during the first } 3 \text { months, when dose } \\
\text { changed from } 0 \text { to } 4 \mathrm{~g} / \text { day, } \mathrm{p}=.0013\end{array}$} & \multicolumn{4}{|c|}{$\begin{array}{l}\text { Non-HDLC decreasing slope during the first } 3 \text { months, when } \\
\text { dose changed from } 0 \text { to } 4 \mathrm{~g} / \mathrm{day}, \mathrm{p}=.01\end{array}$} \\
\hline
\end{tabular}


Table 3 Body weight and blood pressure at each visit in 5 subjects, where the Lovaza sequence was 4,4,4,4,4,4,4 g/day

\begin{tabular}{|c|c|c|c|c|c|c|c|c|c|c|}
\hline \multirow[t]{2}{*}{ Visit } & \multirow[t]{2}{*}{ Dose } & \multicolumn{3}{|c|}{ Body weight (lb) } & \multicolumn{3}{|c|}{ Systolic BP (mmHg) } & \multicolumn{3}{|c|}{ Diastolic BP (mmHg) } \\
\hline & & Mean \pm SD & median & p vs Visit 0 & Mean \pm SD & median & p vs Visit 0 & Mean \pm SD & median & p vs Visit 0 \\
\hline 0 & 0 & $209 \pm 51$ & 216 & & $126 \pm 19$ & 120 & & $86 \pm 14$ & 80 & \\
\hline 1 & 4 & $202 \pm 54$ & 214 & & $116 \pm 15$ & 110 & & $75 \pm 11$ & 80 & .05 \\
\hline 2 & 4 & $202 \pm 51$ & 214 & & $110 \pm 7$ & 110 & .04 & $77 \pm 8$ & 80 & \\
\hline 3 & 4 & $199 \pm 49$ & 211 & & $116 \pm 14$ & 110 & & $78 \pm 13$ & 76 & \\
\hline 4 & 4 & $199 \pm 50$ & 209 & & $121 \pm 17$ & 130 & & $74 \pm 10$ & 78 & .05 \\
\hline 5 & 4 & $202 \pm 51$ & 214 & & $122 \pm 13$ & 118 & & $78 \pm 5$ & 80 & \\
\hline 6 & 4 & $201 \pm 60$ & 225 & & $122 \pm 2$ & 122 & & $77 \pm 6$ & 80 & \\
\hline 7 & 4 & $201 \pm 59$ & 224 & & $120 \pm 12$ & 116 & & $77 \pm 6$ & 77 & \\
\hline
\end{tabular}

In 7 subjects, where the Lovaza sequence was 4, 8, 12, 4, 4, 4,4 g/day

\begin{tabular}{|c|c|c|c|c|c|c|c|c|c|c|}
\hline \multirow[t]{2}{*}{ Visit } & \multirow[t]{2}{*}{ Dose } & \multicolumn{3}{|c|}{ Body weight (lb) } & \multicolumn{3}{|c|}{ Systolic BP (mmHg) } & \multicolumn{3}{|c|}{ Diastolic BP $(\mathrm{mmHg})$} \\
\hline & & Mean \pm SD & median & p vs Visit 0 & Mean \pm SD & median & p vs Visit 0 & Mean \pm SD & median & p vs Visit 0 \\
\hline 0 & 0 & $251 \pm 30$ & 246 & & $138 \pm 28$ & 124 & & $88 \pm 13$ & 86 & \\
\hline 1 & 4 & $251 \pm 31$ & 246 & & $139 \pm 25$ & 132 & & $88 \pm 9$ & 86 & \\
\hline 2 & 8 & $253 \pm 28$ & 247 & & $129 \pm 23$ & 124 & & $85 \pm 18$ & 78 & \\
\hline 3 & 12 & $250 \pm 29$ & 242 & & $122 \pm 10$ & 122 & & $84 \pm 17$ & 80 & \\
\hline 4 & 4 & $250 \pm 31$ & 242 & & $121 \pm 12$ & 120 & .05 & $79 \pm 8$ & 80 & .05 \\
\hline 5 & 4 & $251 \pm 29$ & 249 & & $130 \pm 16$ & 130 & & $85 \pm 12$ & 82 & \\
\hline 6 & 4 & $247 \pm 33$ & 244 & & $136 \pm 24$ & 132 & & $83 \pm 14$ & 80 & \\
\hline 7 & 4 & $243 \pm 34$ & 235 & .002 & $132 \pm 24$ & 124 & & $78 \pm 12$ & 76 & .02 \\
\hline \multicolumn{11}{|c|}{ In 3 non-responders, where the Lovaza sequence was $4,8,12,4,4,4,4 \mathrm{~g} /$ day } \\
\hline \multirow[t]{2}{*}{ Visit } & \multirow[t]{2}{*}{ Dose } & \multicolumn{3}{|c|}{ Body weight (lb) } & \multicolumn{3}{|c|}{ Systolic BP (mmHg) } & \multicolumn{3}{|c|}{ Diastolic BP (mmHg) } \\
\hline & & Mean \pm SD & median & p vs Visit 0 & Mean \pm SD & median & p vs Visit 0 & Mean \pm SD & median & p vs Visit 0 \\
\hline 0 & 0 & $204 \pm 10$ & 204 & & $121 \pm 17$ & 120 & & $84 \pm 4$ & 85 & \\
\hline 1 & 4 & $202 \pm 11$ & 196 & & $115 \pm 15$ & 110 & & $77 \pm 7$ & 76 & \\
\hline 2 & 8 & $198 \pm 14$ & 191 & & $122 \pm 3$ & 120 & & $87 \pm 6$ & 90 & \\
\hline 3 & 12 & $200 \pm 14$ & 195 & & $125 \pm 8$ & 120 & & $82 \pm 5$ & 84 & \\
\hline 4 & 4 & $198 \pm 13$ & 192 & & $113 \pm 12$ & 120 & & $76 \pm 4$ & 75 & \\
\hline 5 & 4 & $196 \pm 12$ & 190 & .02 & $126 \pm 14$ & 134 & & $79 \pm 10$ & 77 & \\
\hline 6 & 4 & $204 \pm 11$ & 204 & & $129 \pm 1$ & 129 & & $82 \pm 0$ & 82 & \\
\hline 7 & 4 & $202 \pm 19$ & 202 & & $123 \pm 24$ & 123 & & $82 \pm 11$ & 82 & \\
\hline
\end{tabular}

correlation between the changes in insulin, weight, and TG from visit 0 to visit $1, \mathrm{p}>0.6$.

In the 15 patients, there were 85 patient-months on Lovaza $4 \mathrm{~g} /$ day, 10 patient- months on $8 \mathrm{~g} /$ day, and 10 patient-months on $12 \mathrm{~g} /$ day. Compared to pre-Lovaza baseline, no abnormal measures developed in laboratory safety tests ( $>0.1$ ) on 4,8 , or $12 \mathrm{~g} /$ day Lovaza therapy. The 4,8 , and $12 \mathrm{~g} / \mathrm{d}$ Lovaza doses were well tolerated, and adherence by pill count was $>95 \%$ for all treatment groups.

\section{Discussion}

In the current study, after treating HTG with a conventional TG-lowering regimen (fibric acids, diet, diabetes control, and metformin, when hyperinsulinemic), 5 patients were very sensitive to addition of $4 \mathrm{~g}$ Lovaza/ day, with mean TG falling 90\% from $1390 \mathrm{mg} / \mathrm{dl}$ to
$135 \mathrm{mg} / \mathrm{dl}$ and mean non-HDLC falling 53\% from 320 to $152 \mathrm{mg} / \mathrm{dl}$ in 2 months. Moreover, at 2 of 7 monthly visits on Lovaza, diastolic blood pressure was lower than at baseline, an additional beneficial outcome.

In 10 patients with mean TG $1163 \mathrm{mg} / \mathrm{dl}$ despite conventional TG-lowering therapy, 3 patients (baseline mean TG $1369 \mathrm{mg} / \mathrm{dl}$ ) failed to respond significantly to sequential increments of Lovaza from 4 to 8 to $12 \mathrm{~g} /$ day. In 7 of these 10 patients, however, TG fell 37\% from $1075 \mathrm{mg} / \mathrm{dl}$ to $672 \mathrm{mg} / \mathrm{dl}$ on Lovaza $4 \mathrm{~g} /$ day, fell $46 \%$ to $577 \mathrm{mg} / \mathrm{dl}$ on $8 \mathrm{~g} /$ day, and fell $60 \%$ to $428 \mathrm{mg} / \mathrm{dl}$ on $12 \mathrm{~g} /$ day, with a negative TG slope. At the same time, mean non-HDLC fell 11\% from 245 to $217 \mathrm{mg} / \mathrm{dl}, 17 \%$ to $203 \mathrm{mg} / \mathrm{dl}$, and $22 \%$ to $192 \mathrm{mg} / \mathrm{dl}$. Moreover, diastolic blood pressure was lower than baseline at last visits on Lovaza. 


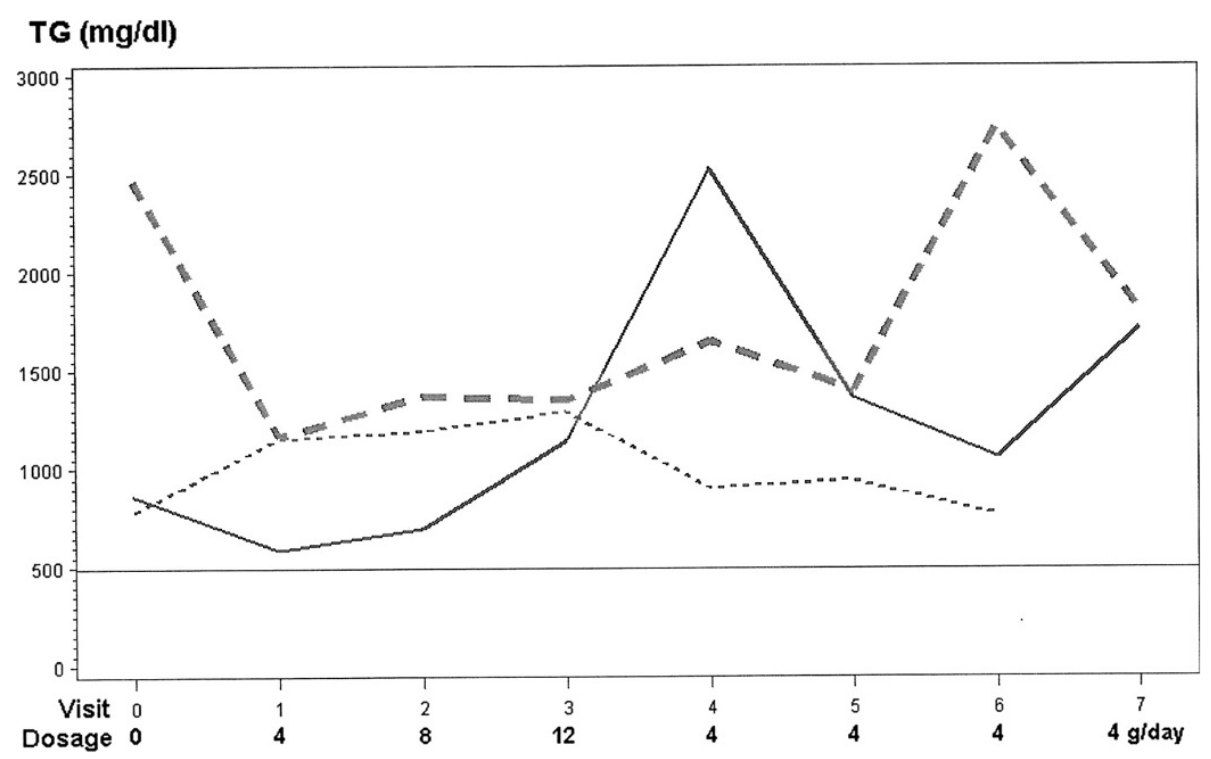

Figure 2 Three subjects whose triglyceride levels failed to fall below $500 \mathrm{mg} / \mathrm{dl}$ despite titration of Lovaza from 4 to 8 to $12 \mathrm{grams} / \mathrm{day}$.

Patients with the ApoE 3-4 genotype were less responsive to Lovaza therapy, congruent with the report by Christidis et al. [15] where triglyceride reduction on fenofibrate was less marked in patients with the ApoE4 allele.

Titration of the Lovaza to $8 \mathrm{~g} /$ day (10 patient-months) and $12 \mathrm{~g} /$ day (10 patient- months) in 10 patients did not adversely affect any laboratory safety tests, did not produce petechiae or purpura, and was well tolerated. This is a limited experience, however, with regard to safety of 8 and $12 \mathrm{~g} /$ day of Lovaza, and is a limitation of the current study.

Another limitation of the current study was the failure to measure plasma, red blood cell, and leukocyte fatty acid profiles and compare these with the patients' responses to the stepwise increases in doses of Lovaza.

Our findings in the current study are congruent with previous studies in hypertriglyceridemic patients given up to $15 \mathrm{~g} /$ day of omega-3 fatty acids [6-12]. Harris et al. [9] gave 4.5,7.5, and $12 \mathrm{~g} / \mathrm{d}$ of omega-3 fatty acids for 3 successive 6 week periods to 10 hypertriglyceridemic patients, and triglycerides fell from 540 to 257 to 248 to $208 \mathrm{mg} / \mathrm{dl}$ as the dose increased, $\mathrm{p}<.01$ versus baseline for each. In 22 women with median entry triglycerides $1087 \mathrm{mg} / \mathrm{dl}$, Goldenberg et al. [7] safely titrated omega-3 fatty acids up to $12 \mathrm{~g} /$ day, with triglycerides falling to a median of $326 \mathrm{mg} / \mathrm{dl}$. In 4 women whose initial triglyceride levels were $>750 \mathrm{mg} / \mathrm{dl}$ despite conventional triglyceride-lowering therapy, Glueck et al. [8] safely titrated omega- 3 fatty acids up to $15 \mathrm{~g} / \mathrm{d}$. Sanders et al. [10] safely treated 5 patients with primary hypertriglyceridemia with $15 \mathrm{~g} / \mathrm{d}$ of omega-3 fatty acids over a 4 week period with mean triglyceride levels falling from 1147 to $558 \mathrm{mg} / \mathrm{dl}$.

A triglyceride concentration above $1,000 \mathrm{mg} / \mathrm{dl}$ is an indication for therapy to lower the risk of acute

Table 4 TG and Non-HDLC at each visit during treatment In 3 non-responders, where the Lovaza sequence was 4, 8,12, 4, 4, 4, 4 g/day

\begin{tabular}{|c|c|c|c|c|c|c|c|}
\hline \multirow[t]{2}{*}{ Visit } & \multirow{2}{*}{$\begin{array}{l}\text { Dosage } \\
\text { (g/day) }\end{array}$} & \multicolumn{3}{|l|}{ TG (mg/dl) } & \multicolumn{3}{|c|}{ Non-HDLC (mg/dl) } \\
\hline & & Mean \pm SD & median & p vs Visit 0 & Mean \pm SD & median & p vs Visit 0 \\
\hline 0 & 0 & $1369 \pm 950$ & 859 & & $256 \pm 79$ & 221 & \\
\hline 1 & 4 & $970 \pm 328$ & 1154 & & $258 \pm 121$ & 229 & \\
\hline 2 & 8 & $1086 \pm 348$ & 1190 & & $235 \pm 86$ & 199 & \\
\hline 3 & 12 & $1260 \pm 108$ & 1290 & & $242 \pm 121$ & 211 & \\
\hline 4 & 4 & $1693 \pm 816$ & 1650 & & $301 \pm 85$ & 347 & \\
\hline 5 & 4 & $1233 \pm 255$ & 1360 & & $248 \pm 86$ & 237 & \\
\hline 6 & 4 & $1522 \pm 1065$ & 1060 & & $263 \pm 51$ & 266 & \\
\hline 7 & 4 & $1760 \pm 71$ & 1760 & & $246 \pm 42$ & 245 & \\
\hline
\end{tabular}




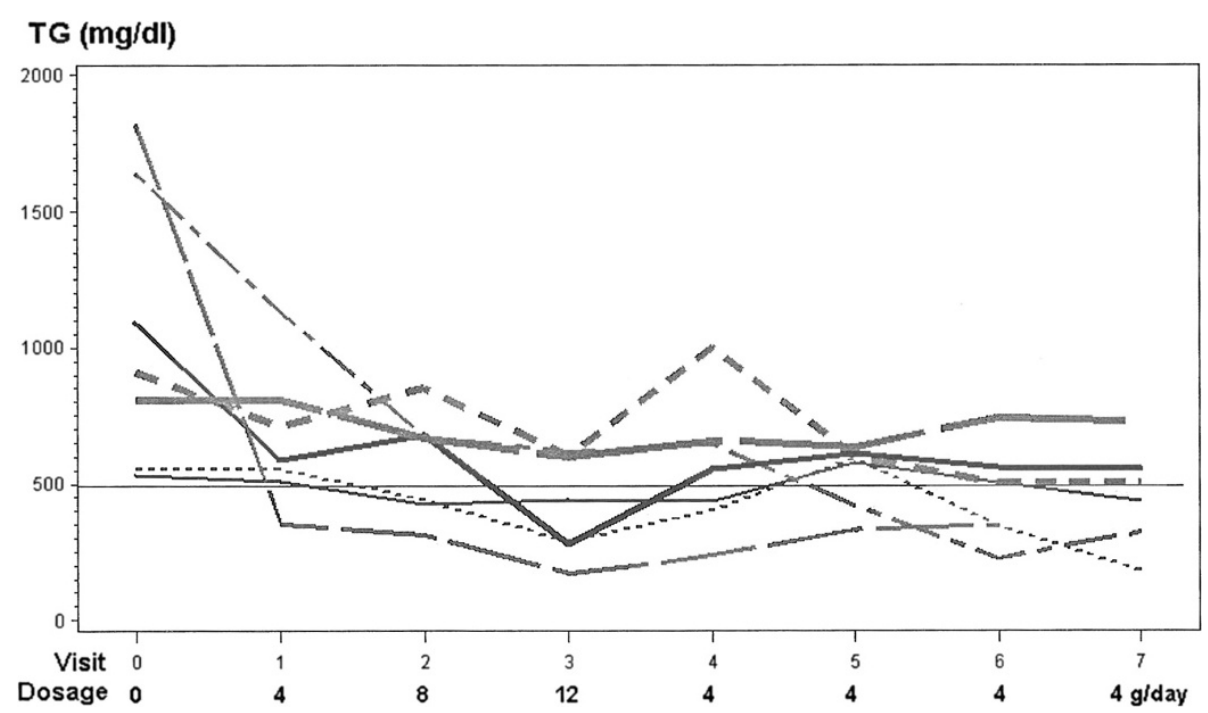

Figure 3 Seven subjects whose triglyceride levels fell as Lovaza was titrated from 4 to 8 to 12 grams/day.

pancreatitis, while in subjects with TG levels below $1,000 \mathrm{mg} / \mathrm{dl}$ the indication for treatment is primarily to reduce the risk of clinical events caused by atherosclerosis [7,8,16-18]. The relationship between hypertriglyceridemia and coronary heart disease is abolished when non-HDL cholesterol and HDL cholesterol concentrations are controlled for [19].

Omega-3 fatty acids have successfully been used in treatment of severe primary HTG [7,20,21]. Omega-3 fatty acids and fenofibrate have similar TG-lowering effects and promote similar changes in endotheliumdependent dilation, but fenofibrate therapy has substantially better effects on lipoprotein and metabolic profiles in patients with HTG [22]. In severe HTG, fibric acids and omega-3 fatty acids are often used concurrently
$[7,8,23,24]$. In the current study, we did not add nicotinic acid to the entry conventional TG lowering regimen (low fat diet $[<25 \%$ of calories as fat], fibric acids, metformin reduction of insulin resistance, diabetes control) to avoid worsening [25-28] of type 2 diabetes, conversion of impaired fasting glucose to levels $\geq 126 \mathrm{mg} / \mathrm{dl}$, or worsening insulin resistance-hyperinsulinemia in patients with antecedent hyperinsulinemia.

Bays et al. [21] carried out a placebo-controlled randomized study of 229 diet-stable patients with fasting TG $\geq 500 \mathrm{mg} / \mathrm{dl}$ and $\leq 2,000 \mathrm{mg} / \mathrm{dl}$. Mean baseline TG levels were 680,657 , and $703 \mathrm{mg} / \mathrm{dl}$ for eicosapentaenoic acid ethyl ester (AMR101) $4 \mathrm{~g} /$ day, AMR101 $2 \mathrm{~g} /$ day, and placebo. AMR101 $4 \mathrm{~g} /$ day reduced the placebocorrected TG levels by 33.1\% ( $\mathrm{p}<.0001)$ and AMR101

Table 5 TG and Non-HDLC in 7 subjects, where the Lovaza sequence was 4, 8, 12, 4, 4, 4 , 4 g/day

\begin{tabular}{|c|c|c|c|c|c|c|c|c|c|}
\hline \multirow[t]{2}{*}{ Visit } & \multirow{2}{*}{$\begin{array}{l}\text { Dosage } \\
\text { (g/day) }\end{array}$} & \multicolumn{4}{|l|}{ TG (mg/dl) } & \multicolumn{4}{|c|}{ Non-HDLC (mg/dl) } \\
\hline & & Mean \pm SD & median & $\begin{array}{l}\% \text { change, } \\
\text { p vs Visit } 0\end{array}$ & $\mathrm{p}^{*}$ (vs former Visit) & Mean \pm SD & median & $\begin{array}{l}\% \text { change, } \\
\text { p vs Visit } 0\end{array}$ & $\mathrm{p}^{*}$ (vs former Visit) \\
\hline 0 & 0 & $1075 \pm 525$ & 857 & & & $245 \pm 88$ & 214 & & \\
\hline 1 & 4 & $672 \pm 247$ & 587 & $-37 \%, .006$ & & $217 \pm 62$ & 223 & $-11 \%$ & \\
\hline 2 & 8 & $577 \pm 189$ & 666 & $-46 \%, .0009$ & NS & $203 \pm 44$ & 199 & $-17 \%, .01$ & NS \\
\hline 3 & 12 & $428 \pm 184$ & 443 & $-60 \%,<.0001$ & .03 & $192 \pm 61$ & 164 & $-22 \%, .003$ & NS \\
\hline 4 & 4 & $561 \pm 244$ & 554 & .0006 & .03 & $203 \pm 49$ & 185 & .01 & NS \\
\hline 5 & 4 & $538 \pm 115$ & 593 & .0004 & & $205 \pm 44$ & 233 & .01 & \\
\hline 6 & 4 & $459 \pm 171$ & 502 & $<.0001$ & & $189 \pm 31$ & 185 & .001 & \\
\hline \multirow[t]{2}{*}{7} & 4 & $430 \pm 191$ & 395 & $<.0001$ & & $171 \pm 43$ & 164 & .0002 & \\
\hline & & \multicolumn{4}{|c|}{$\begin{array}{l}\text { TG decreasing slope during the first } 3 \text { months, when the Lovaza } \\
\text { dose was increased from } 0 \text { to } 12 \mathrm{~g} / \text { day, } \mathrm{p}=.0018\end{array}$} & \multicolumn{4}{|c|}{$\begin{array}{l}\text { Non-HDLC decreasing slope during the first } 3 \text { months, when th } \\
\text { Lovaza dose was increased from } 0 \text { to } 12 \mathrm{~g} / \text { day, } \mathrm{p}=.016\end{array}$} \\
\hline
\end{tabular}

p: comparison of Least-square means using Mixed model.

$\mathrm{p}^{*}$ : paired Wilcoxon test for the change from Visit 1 to Visit 2 (dosage from $4 \mathrm{~g} /$ day to 8 ); from Visit 2 to Visit 3 (dosage from $8 \mathrm{~g} /$ day to 12 ); from Visit 3 to Visit 4 (dosage from $12 \mathrm{~g} /$ day to 4 ). 
$2 \mathrm{~g} /$ day by $19.7 \%$ ( $\mathrm{p}=.0051$ ). For patients with baseline TG levels $>750 \mathrm{mg} / \mathrm{dl}$, AMR101 $4 \mathrm{~g} /$ day reduced the placebo-corrected TG levels by 45.4\% $(\mathrm{p}=.0001)$ and AMR101 $2 \mathrm{~g} /$ day by 32.9\% ( $\mathrm{p}=.0016)$. AMR101 significantly reduced non-HDLC.

Another approach to the stepped management of the type of severely hypertriglyceridemic patients described in this report would be to lower TG to $<1,000 \mathrm{mg} / \mathrm{dL}$ with Lovaza, and then add atorvastatin, $80 \mathrm{mg} /$ day, or rosuvastatin, $40 \mathrm{mg} /$ day [29].

\section{Conclusion}

In patients with severe primary HTG despite conventional TG lowering therapy, addition of Lovaza $4 \mathrm{~g}$ per day, and where necessary, increasing to 8 or $12 \mathrm{~g}$ per day safely further lowers TG in a linear fashion.

\section{Methods}

\section{Study design, patients}

The study followed a protocol approved by the Jewish Hospital IRB, with signed informed consent, and after an entry visit, included 8 subsequent visits at monthly intervals. Patients were instructed in a eucaloric diet with total fat restricted to no more than $25 \%$ to $30 \%$ of calories [30] at the entry visit by registered dietitians, with no alcohol intake. At each monthly visit, dietary adherence was reviewed by the dietitians, using 24-hour recall. Weight loss was not a targeted goal during the 8month treatment period.

\section{Inclusion criteria}

Inclusion criteria included primary HTG [18] with fasting TG levels $>1000 \mathrm{mg} / \mathrm{dl}$, and persistence of TG levels $>500 \mathrm{mg} / \mathrm{dl}$ despite conventional TG lowering therapy for 1 month, including diet, control of type 2 diabetes mellitus, fibric acids, and, where indicated, metformin for treatment of hyperinsulinemia. Type 1 diabetics were excluded; three type 2 diabetics with stable hemoglobin A1C control were included.

\section{Exclusion criteria}

1. Patients with known allergy to fish.

2. HTG secondary to alcoholism, exogenous corticosteroids or estrogens, nephrotic syndrome, hemochromatosis, glycogen storage disease, uncontrolled diabetes, Cushing's syndrome, uremia.

3. Bleeding gastric or duodenal ulcers, active inflammatory bowel disease.

4. Pregnancy.

5. Dementia.

After an overnight fast, blood was obtained for entry measurement of lipid profile, complete blood count, fasting glucose, hemoglobin A1C (HbA1C), insulin, Cpeptide, renal and liver function tests, $\mathrm{T} 4$ and $\mathrm{TSH}$, and apo E genotype. At each of 8 subsequent visits, blood was drawn for lipid profile, complete blood count, glucose, $\mathrm{HbA1C}$, renal and liver function, insulin, and $\mathrm{C}$ peptide. At entry, and at each subsequent visit, dermatologic examinations were carried out to record any petechiae or bruising. At entry, and at 8 subsequent visits, weight and blood pressure were measured, and a brief physical exam was carried out. At each visit, adherence to the targeted Lovaza dose was assessed by pill count, and adherence to diet by a 24-hour diet recall.

\section{Lovaza Dose Schedule, serial monthly visits Visit -1 (Entry)}

Patients referred to our center with TG $>1,000 \mathrm{mg} / \mathrm{dl}$ were instructed in a eucaloric diet with total fat restricted to no more than $25 \%$ to $30 \%$ of calories [30], with alcohol restricted to zero. If the patient was not already taking fenofibrate $145 \mathrm{mg} /$ day or gemfibrozil $1.2 \mathrm{~g} /$ day, these therapies were instituted. All the 3 patients with type 2 diabetes received metformin $2.5 \mathrm{~g} /$ day, and one (with $\mathrm{HbA} 1 \mathrm{C}>7.2 \%$ ) also received liraglutide $1.8 \mathrm{mg} /$ day. Nicotinic acid was not used since many of the patients either had type 2 diabetes mellitus, or impaired fasting glucose, or hyperinsulinemia which were relative contraindications [25-28] to its use. Patients with impaired fasting glucose and/or fasting hyperinsulinemia $(>24.9 \mathrm{uU} / \mathrm{ml})$ were also treated with metformin [31,32], $2.5 \mathrm{~g} /$ day.

\section{Visit 0 (Baseline)}

One month after visit -1 , if TG remained $>500 \mathrm{mg} / \mathrm{dl}$ despite conventional TG lowering therapy, then patients were instructed to start Lovaza, $2 \mathrm{~g}$ with breakfast, $2 \mathrm{~g}$ with the evening meal, while continuing their antecedent TG lowering therapy unchanged, and dietary instruction was reinforced.

\section{Visit 1}

One month after visit 0 , if TG had fallen to $<500 \mathrm{mg} / \mathrm{dl}$, Lovaza was held at $4 \mathrm{~g} /$ day. If TG remained $>500 \mathrm{mg} / \mathrm{dl}$, Lovaza was increased to $8 \mathrm{~g} /$ day, with other components of the TG lowering regimen held stable throughout.

\section{Visit 2}

One month after visit 1 , if TG had fallen to $<500 \mathrm{mg} / \mathrm{dl}$ on $8 \mathrm{~g} /$ day, the Lovaza dose was kept at $8 \mathrm{~g} /$ day, but if TG remained $>500 \mathrm{mg} / \mathrm{dl}$, Lovaza was increased from 8 to $12 \mathrm{~g}$ per day, with other components of the TG lowering regimen held stable. 


\section{Visit 3}

One month after visit 2, Lovaza was diminished in all patients to $4 \mathrm{~g} /$ day.

\section{Visits 4-7}

Four monthly visits after visit 3; Lovaza kept at $4 \mathrm{~g} /$ day.

\section{Statistical analysis}

All statistical analysis was done using SAS 9.1.3.

For each treatment group (according to Lovaza dosage sequences), mean $\pm \mathrm{SD}$ and median TG, non-HDLC, body weight and blood pressure (BP) at each visit were calculated. Changes from baseline to follow-up were tested using MIXED model, with visit as fixed effect, subject as random effect, and comparison of least square means (SAS proc MIXED).

For each treatment group, MIXED model for TG was constructed for the first 3 months on Lovaza, fixed effect was time (visit order), random effect was subject, with repeated measures had $\mathrm{AR}(1)$ variance structure. Using MIXED model, the TG slope was assessed.

Paired Wilcoxon tests were used to assess the effect of changes of Lovaza dosage (from 4 to $8 \mathrm{~g}$ /day, from 8 to $12 \mathrm{~g} /$ day, from 12 to $4 \mathrm{~g} /$ day) on TG and non-HDLC.

\section{Abbreviations \\ (HTG): Primary hypertriglyceridemia; (TG): triglyceride; (HDLC): high density lipoprotein cholesterol; (non-HDLC): non high density lipoprotein cholesterol.}

\section{Competing interests}

Beyond provision of support by way of drug and partial funding by GSK, the authors have no conflict of interest, including membership in speaker's bureau or corporate advisory committee, stockholder, or travel support. No conflicts of interest with competing products.

\section{Authors' contributions}

Drs NK, CJG, and PW participated in all aspects of the manuscript, study design, data collection, data editing, data analysis, production of manuscript. Drs ZK, MR, and JP participated in data collection, data editing, data analysis, production of manuscript. All authors read and approved the final manuscript.

\section{Acknowledgements}

Supported in part by the Lipoprotein Research Fund, Jewish Hospital of Cincinnati.

Supported in part by GSK by way of drug and funding.

Received: 20 June 2012 Accepted: 26 October 2012

Published: 30 October 2012

\section{References}

1. Calabresi L, Donati D, Pazzucconi F, Sirtori CR, Franceschini G: Omacor in familial combined hyperlipidemia: effects on lipids and low density lipoprotein subclasses. Atherosclerosis 2000, 148(2):387-96.

2. Davidson MH, Kling D, Maki KC: Novel developments in omega-3 fatty acid-based strategies. Curr Opin Lipidol 2011, 22(6):437-44.

3. Jones PJ, Demonty I, Chan YM, Herzog Y, Pelled D: Fish-oil esters of plant sterols differ from vegetable-oil sterol esters in triglycerides lowering, carotenoid bioavailability and impact on plasminogen activator inhibitor-1 (PAl-1) concentrations in hypercholesterolemic subjects. Lipids Health Dis 2007, 6:28.

4. Sadovsky R, Kris-Etherton P: Prescription omega-3-acid ethyl esters for the treatment of very high triglycerides. Postgrad Med 2009, 121(4):145-53.
5. Barter $\mathrm{P}$, Ginsberg HN: Effectiveness of combined statin plus omega-3 fatty acid therapy for mixed dyslipidemia. Am J Cardio/ 2008, 102(8):1040-5.

6. Glueck CJ, Streicher P, Wang P, Sprecher D, Falko JM: Treatment of severe familial hypertriglyceridemia during pregnancy with very-low-fat diet and n-3 fatty acids. Nutrition 1996, 12(3):202-5.

7. Goldenberg NM, Wang P, Glueck CJ: An observational study of severe hypertriglyceridemia, hypertriglyceridemic acute pancreatitis, and failure of triglyceride-lowering therapy when estrogens are given to women with and without familial hypertriglyceridemia. Clin Chim Acta 2003, 332(1-2):11-9.

8. Glueck CJ, Lang J, Hamer T, Tracy T: Severe hypertriglyceridemia and pancreatitis when estrogen replacement therapy is given to hypertriglyceridemic women. J Lab Clin Med 1994, 123(1):59-64.

9. Harris WS, Rothrock DW, Fanning A, Inkeles SB, Goodnight SH Jr, Illingworth DR, Connor WE: Fish oils in hypertriglyceridemia: a dose-response study. Am J Clin Nutr 1990, 51(3):399-406.

10. Sanders TA, Sullivan DR, Reeve J, Thompson GR: Triglyceride-lowering effect of marine polyunsaturates in patients with hypertriglyceridemia. Arteriosclerosis 1985, 5(5):459-65.

11. Schectman G, Kaul S, Cherayil GD, Lee M, Kissebah A: Can the hypotriglyceridemic effect of fish oil concentrate be sustained? Ann Intern Med 1989, 110(5):346-52.

12. Svaneborg N, Moller JM, Schmidt EB, Varming $K$, Lervang $H H$, Dyerberg J: The acute effects of a single very high dose of $n-3$ fatty acids on plasma lipids and lipoproteins in healthy subjects. Lipids 1994, 29(2):145-7.

13. Brouwers MC, de Graaf J, van Greevenbroek MM, Schaper N, Stehouwer CD, Stalenhoef AF: Novel drugs in familial combined hyperlipidemia: lessons from type 2 diabetes mellitus. Curr Opin Lipidol 2010, 21(6):530-8.

14. Grundy SM, Cleeman JI, Merz CN, Brewer HB Jr, Clark LT, Hunninghake DB, Pasternak RC, Smith SC Jr, Stone NJ: Implications of recent clinical trials for the National Cholesterol Education Program Adult Treatment Panel III guidelines. Arterioscler Thromb Vasc Biol 2004, 24(8):e149-61.

15. Christidis DS, Liberopoulos EN, Kakafika Al, Miltiadous GA, Cariolou M, Ganotakis ES, Mikhailidis DP, Elisaf MS: The effect of apolipoprotein E polymorphism on the response to lipid-lowering treatment with atorvastatin or fenofibrate. J Cardiovasc Pharmacol Ther 2006, 11(3):211-21.

16. Neil HA, Cooper J, Betteridge DJ, Capps N, McDowell IF, Durrington PN, Seed M, Mann Jl, Humphries SE: All-cause and cardiovascular mortality in treated patients with severe hypertriglyceridaemia: A long-term prospective registry study. Atherosclerosis 2010, 211(2):618-23.

17. Brunzell JD, Bierman EL: Chylomicronemia syndrome. Interaction of genetic and acquired hypertriglyceridemia. Med Clin North Am 1982, 66(2):455-68.

18. Greenberg BH, Blackwelder WC, Levy Rl: Primary type V hyperlipoproteinemia. A descriptive study in 32 families. Ann Intern Med 1977, 87(5):526-34

19. Di Angelantonio E, Sarwar N, Perry P, Kaptoge S, Ray KK, Thompson A, Wood AM, Lewington S, Sattar N, Packard CJ, Collins R, Thompson SG, Danesh J: Major lipids, apolipoproteins, and risk of vascular disease. JAMA 2009, 302(18):1993-2000.

20. Richter WO, Jacob BG, Ritter MM, Schwandt P: Treatment of primary chylomicronemia due to familial hypertriglyceridemia by omega-3 fatty acids. Metabolism 1992, 41(10):1100-5.

21. Bays HE, Ballantyne CM, Kastelein JJ, Isaacsohn JL, Braeckman RA, Soni PN: Eicosapentaenoic acid ethyl ester (AMR101) therapy in patients with very high triglyceride levels (from the Multi-center, plAcebo-controlled, Randomized, double-blINd, 12-week study with an open-label Extension [MARINE] trial). Am J Cardio/ 2011, 108(5):682-90.

22. Koh KK, Quon MJ, Shin KC, Lim S, Lee Y, Sakuma I, Lee K, Han SH, Shin EK: Significant differential effects of omega-3 fatty acids and fenofibrate in patients with hypertriglyceridemia. Atherosclerosis; 2011.

23. Wierzbicki AS, Mikhailidis DP, Wray R: Drug treatment of combined hyperlipidemia. Am J Cardiovasc Drugs 2001, 1(5):327-36.

24. Garg A: Treatment of diabetic dyslipidemia. Am J Cardiol 1998, 81(4A):47B-51B

25. Grundy SM: Atlas of Atherosclerosis and Metabolic Syndrome. 2010.

26. Kaushik SV, Plaisance EP, Kim T, Huang EY, Mahurin AJ, Grandjean PW, Mathews ST: Extended-release niacin decreases serum fetuin-A concentrations in individuals with metabolic syndrome. Diabetes Metab Res Rev 2009, 25(5):427-34. 
27. Kreisberg RA: Diabetic dyslipidemia. Am J Cardiol 1998, 82(12A):67-73 discussion 85U-6U.

28. Vittone F, Chait A, Morse JS, Fish B, Brown BG, Zhao XQ: Niacin plus Simvastatin Reduces Coronary Stenosis Progression Among Patients with Metabolic Syndrome Despite a Modest Increase in Insulin Resistance: A Subgroup Analysis of the HDL-Atherosclerosis Treatment Study (HATS). J Clin Lipidol 2007, 1(3):203-10.

29. Stein $E A$, Lane $M$, Laskarzewski P: Comparison of statins in hypertriglyceridemia. Am J Cardiol 1998, 81(4A):66B-9B.

30. Levy Rl, Bonnell M, Ernst ND: Dietary management of hyperlipoproteinemia. J Am Diet Assoc 1971, 58(5):406-16.

31. Li XM, Li Y, Zhang NN, Xie YH, Shi YQ: Combination therapy with metformin and fenofibrate for insulin resistance in obesity. J Int Med Res 2011, 39(5):1876-82.

32. Malin SK, Gerber R, Chipkin SR, Braun B: Independent and combined effects of exercise training and metformin on insulin sensitivity in individuals with prediabetes. Diabetes Care 2012, 35(1):131-6.

doi:10.1186/1476-511X-11-143

Cite this article as: Glueck et al: Titrating lovaza from 4 to 8 to 12 grams/day in patients with primary hypertriglyceridemia who had triglyceride levels $>500 \mathrm{mg} / \mathrm{dl}$ despite conventional triglyceride lowering therapy. Lipids in Health and Disease 2012 11:143.

\section{Submit your next manuscript to BioMed Central and take full advantage of:}

- Convenient online submission

- Thorough peer review

- No space constraints or color figure charges

- Immediate publication on acceptance

- Inclusion in PubMed, CAS, Scopus and Google Scholar

- Research which is freely available for redistribution 